\title{
Bacterial Canker of Tomato
}

\section{AZIZ BAGHERI ${ }^{\otimes}$}

Department of Plant Protection Researches, Hamedan Agricultural and Natural Resources Research and Education Center, AREEO, Hamedan, Iran ( $\square$ : bagherisa78@gmail.com)

Received: 28.08.2017

Accepted: 26.01.2018

Bagheri A. 2018. Bacterial canker of tomato. Plant Pathology Science 7(2):14-21. DOI: 10.2982/PPS.7.2.14

Abstract: Bacterial canker of tomato caused by Clavibacter michiganensis subsp. michiganensis is one of the most important and economical diseases of tomato. Pale, yellow, dry leaves and shoots with colorless strips are the main symptoms on infected plants. The canker is formed in the last stages of the disease. Use of pathogen-free seeds or seedlings, implementation of quarantine regulations in infected areas, fallow and rotation with plants out of the Solanaceae family, plowing after tomatoes harvesting and drip irrigation are the main management strategies for disease control. Spraying copper chemicals can also help disease control.

Key words: Canker, Tomato, Clavibacter

$$
\begin{aligned}
& \text { بيمارى شانكر باكتر يايى گَوجهفرنكى } \\
& \text { عزيز باقرى } \\
& \text { بخش تحقيقات كياهيزشكى مركز تحقيقات و آموزش كشاورزى و منابع طبيعى استان همدان، سازمان } \\
& \text { تحقيقات، آموزش و ترويج كشاورزى، همدان، ايران }
\end{aligned}
$$

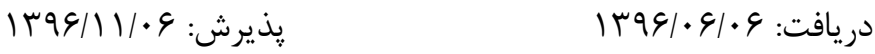


كوجهفرنكى (Lycopersicon esculentum Mill) يكى از مهمترين محصولات كشاورزى است كه بلهورت تازه و فرآورى شده مصرف مىشود. يكى از بيمارىهاى مهمم اين گياه، بيمارى شانكر باكتريايى مىباشد كه اولين بار در سال 9 • 19 از ايالت ميشيگان آمريكا گزارش شده است (Smith 1910). سيس از كانادا، استراليا، برخى كشورهاى ارويايى، آمريكاى مركزى و جنوبى، آفريقايى و آسيايى گزارش گرديدهاست (Goto 1992). تاكنون از تمام مناطق ارويا، آفريقا، امريكاى شمالى و جنوبى و اقيانوسيه كزارش شده است. يكى از بيمارىهاى مهمم و اقتصادى مزارع و كلخانههاى گوجهفرنكى در كانادا اين بيمارى مىباشد. شانكر باكتريايى ابتدا بلهورت لكههاى سياه بافت مرده در حاشيه بركهاى مسنتر ديده مىشود. لكههاى بافت مرده در اثر ورود باكترى از طريق روزنههاى آبى برگها به داخل بافت برگها به وجود مىآيد. بنابراين، باكترى در سطح بركها تكثيرشده و با رشد كياه اغلب بهصورت لكههاى سفيد كوجكى روى ميوههاى سبز و جوان ديده مىشود. اين نوع لكهها بهعنوان لكههاى جشم يرندهاى معروف است و از مشخصات بيمارى شانكر مىباشد. خسارت بيمارى در مزرعه و كلخانههاى آمريكا را تا •V درصد گزارش و دماى مناسب براى ايجاد آلود مههمترين بيمارىهاى گوجهفرنكى در مزرعه و كلخانه مىباشد. بيمارى در كياه مىتواند بلصورت سيستميك و سطحى ميزبان را آلوده كند و سبب يزمردگى، سبز خشكى و نامرغوبى ميوه شود (Zitter 1985). عامل Clavibacter michiganensis subsp. michiganensis corrig. (Smith 1910) Davis et al.1984 بيمارى است (Davis 1984, Smith 1910) كه يك باكترى گرم مثبت است كه در آوند جوبى كياه توسعهيافته و سبب نشانهاى يرمردگى و شانكر مىشود. اين باكترى دو نوع پِلاسميد دارد كه در بيان زنهاى بيمارىزا و نوع نشانههاى بيمارى در ميزبانهاى مختلف مههم هستند (Garteman et al. 2003). اكرجه كَجهفرنكى ميزبان اصلى Clavibacter michiganensis subsp. michiganensis است اما نشانههاى بيمارى در فلفل شيرين، بادمجان و بسيارى از گونههاى علف هرز متعلق به خانواده سولاناسه نيز گزارش شده است كه در راهكارهاى كنترل بيمارى شناخت ميزبانهاى عامل بيمارى مهمم است(Agrawal et al. 2012). تاكنون از روشهاى كوناكونى براى تشخيص و جداسازى عامل بيمارى از بذور و بافت گياهى آلوده استفاده شده است. از محيط 
كشت نيمه انتخابى براى جداسازى و از روشهاى سرولوزيكى و آزمونهاى بيوشيميايى، هيبريداسيون DNA و ساير روشهاى مولكولى، آناليز اسيدهاى جرب و الكتروفورز يروتيين براى شناسايى عامل بيمارى استفاده

$$
\text { مىشود }
$$

(Schaad 2001, Rat et al. 1984, Vaerenbergh and Chauveau 1987, Gitaitis and Beaver 1990, Thompson et al. 1989) .

در بررسى روشهاى مختلف انتقال و شدت بيمارى شانكر باكتريايى گوجهفرنكى، زمانى كه ريشه گياهجههاى كوجهفرنكى شانكرى و با سوسيانسيون باكترى عامل بيمارى شانكر تلقيح شدند، سب/N درصد گياهجهها نشانههاى يزمردگى و شانكر را نشان دادند. در تيمار مايهزنى ساقه، نشانهاى بيمارى يس از • إ روز و در مايهزنى ريشه با تأخير و بيشتر از ده روز طول كشيد تا نشانهاى بيمارى ظاهر شود

.(Behrendt et al. 2002, Gleason et al. 1993, Goner 2014)

اولين نشانههاى بيمارى در ايران در سال VY I آدر يك مزرعه كوجهفرنكى از حومه شهرستان اروميه گزارش شد. بيمارى در سال الVسا گسترش وسيعى داشته و علاوه بر آلوده نمودن مزارع گوجهفرنگى اروميه از مناطق مهاباد و اشنويه نيز نمونههاى آلوده جمعآورى گرديد. از مجموع بررسىهاى انجام شده بr جدايه C.michiganensis subsp. اكترى جدا و با كمك آزمونهاى فيزيولوزيكى و بيوشيميايى عامل بيمارى را michiganensis كوجهفرنكى را در مقابل بيمارى شانكر باكتريايى در قالب طرح بلوكهاى كامل تصادفى در كلخانه انجام داد.

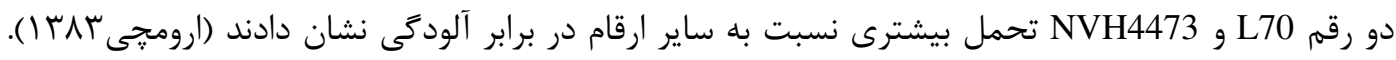

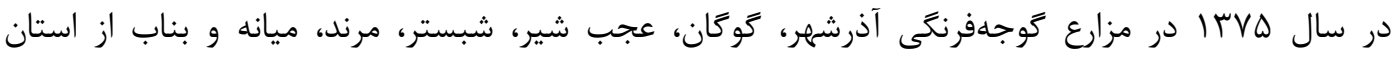
آذربايجان شرقى نشانههاى بيمارى شانكر روى بوتههاى گوجهفرنكى گزارش و تعداد 9.1 جدايه جداسازى و با استفاده از آزمونهاى فيزيولوزيكى، بيوشيميايى و الكتروفورز يروتئين عامل بيمارى را شناسايى كردند

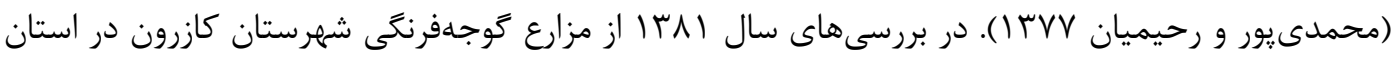
فارس يك باكترى گرم مثبت با يركنه زردرنگ، مسطح، دايرهاى با حاشيه صاف جداسازى شد. بر اساس نتايج 
C. michiganensis subsp. آزمونهاى كلخانهاى و آزمايشگاهى انجام شده باكترى عامل بيمارى michiganensis با توجه به اهميت اقتصادى بيمارى شانكر باكتريايى گَوجهفرنكى و اينكه اين بيمارى در برخى از مناطق هنوز از بيمارىهاى قرنطينهاى مىباشد، هدف اين مقاله شناسايى نشانهاى بيمارى، روشهاى جلوگيرى از كسترش بيمارى و ارائه راهكارهايى جهت مبارزه با آن در مزرعه، كلخانه و انبار مىباشد.

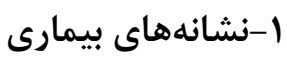

روى نشاها بركهاى كياهجههاى بيمار از حاشيه نكروز شده و بلمرور لكههاى نكروز زرد و قهوهاى مىشوند. روى ساقهها هم لكههاى زرد و قهوهاى و روى برگها و ساقههاى آلوده تاولهاى ريزى به وجود مى آيد. نشاهاى آلوده كوتوله و جند ساقه مىشوند (Zitter 1985). روى بوتههاى بالغ زردى و نكروز بركها در كياهان مسن ييشرفت كرده و حاشيه بركهاى بوتهاى بيمار مثل قرمز آتشين مىشوند. آلودگى در گياه سيستميك شده و جنانجه دمبرى قطع شود تغيير رنگ بافتهاى آوندى مشهود است. در كلخانه بين ركبرگهاى گياهان آلوده لكههاى رنت يريده يا سبز كمرنت ظاهر شده كه اين لكهها بهسرعت بافت مرده و خشى مىشوند. يزمردگى برگها ابتدا از برگهاى مسنتر پايينى شروع مىشود و برگهاى بالاتر ساقه بلهورت نامتقارن رشد مى كنند و بركهاى آلوده ممكن است در يكطرف ساقه از طرف ديگر بيشتر ريزش كنند. بهتدريج در ساقه كياهان آلوده نشانهاى شانكر هم بهوجود مىآيد (Gleason et al. 1993). روى ميوهها در ميوهها نقاط آلوده بهصورت لكههاى كوجى تيره كه توسط يك هاله سفيدرنگ احاطه شده و به جشم يرندكان معروف است ديده مىشوند. اين لكههاى آلوده بهتدريج زرد و قهوهاى رنت شده و خشك مىشوند. در گياهان گلخانه ممكن است اين حالت جشم يرندكان در ميوههاى آلوده مشاهده نشود و ميوه آلوده بلصورت يك دست سفيد مانند سنگ مرمر مشاهده شوند (Sabaratnam 2012) (شكل (). بهطور كلى يزرمردىى بوتهها از نشانه متداول بيمارى است كه از تهاجم باكترى به آوندهاى جوبى و آبكشى، يوست و مغز ساقه ايجاد مىشود. يزمردحى از بركهاى پإيينى شروع مىشود كه ابتدا لكههاى آبسوخته قهوهاى روشن بين ركبرگها ايجاد شده و سيس يزمردىى و مرك بركها روى مىدهد. با يِيشرفت بيمارى نوارهاى قهوهاى رنت و يا شكافهايى در سطح ساقه ظاهر مىشود كه در شرايط مرطوب با تراوشها باكتريايى همراه است. 

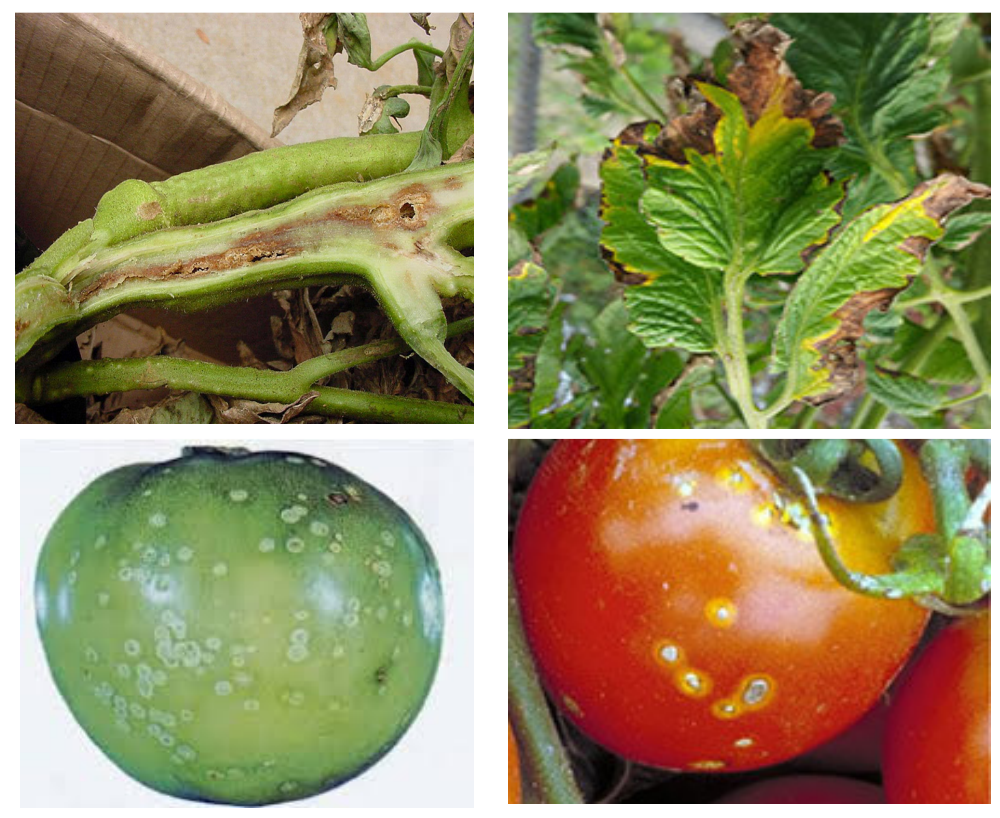

$$
\text { شكل ا - نشانه بيمارى شانكر باكتريايى روى برگ، درون ساقه و روى ميوه گوجهفرنكى(اصلى) }
$$

Figure 1- Symptoms of bacterial canker on leaves, in stem and fruits of tomato (Original) لكههاى مدور به ابعاد دو الى سه ميلىمتر ممكن است روى ميوه، ساقه و برك بهوجود آيند، اين لكهها در

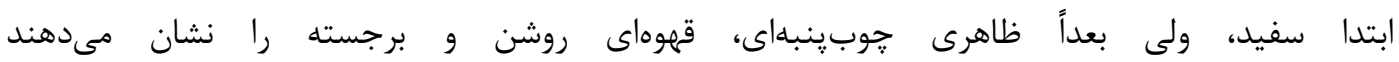
.(Garteman Zitter 1985, et al. 2003 )

\section{r- جرخه بيمارى}

عامل بيمارى حداقل به مدت ينج سال در گوجهفرنكىهاى آلوده و بذور آنها زنده مىماند. همجنين، در بقاياى كياهى آلوده و خاك سه يا جهار هفته تا F F ماه و در بسيارى از محيطهاى زنده و غيرزنده زمانى كه ميزبان اصلى نباشد و در كلخانهها حداقل يك ماه روى سطوح مانند سيمان و يلاستيك زنده مىماند. شرايط مرطوب و خنك به بقاى بيماركر كمك مى كند. دماى مطلوب رشد بيماركر TF تا TF درجه سلسيوس است. برخى از علفهاى هرز مانند تاجريزى و جندين گَونه غير زراعى سولاناسه بهعنوان ميزبان ثانويه باعث بقا و تكثير جمعيت باكترى مىشوند. ذرات آلوده خاى و بقاياى كياهى آلوده با باد، حشرات، باران و آب آبيارى يخش شده و سبب آلودىى كلخانهها و زمينهاى زراعى مىشوند. در هنكام نشاكارى، ابزار آلوده، دستها و لباسهاى كاركران سبب انتقال بيمارى مى گردند (Sabaratnam 2012). 


\section{ب-مديريت بيمارى}

تمامى مراحل رشدى گوجهفرنكى به بيمارى مذكور حساس بوده و آلوده مىشوند. باكترى از روزنههاى بركها، شانكرهاى كوجى روى ساقه و برى گياه وارد ميزبان شده و در گياه آلوده بلصورت سيستميك درمى آيد، بنابراين، از مهرمترين راهكارهاى مديريتى پيشخيرى از آلودگى مىباشد. رعايت اصول بهداشت در طول فصل زراعى ضرورى است. جهت كشت گوجهفرنكى بايستى از بذور سالم و عارى از آلودىى استفاده كرد. آزمون سلامت نشاهايى كه براى كشت در نظر كرفته مىشوند بايد انجام شود. جهت تهيه نشا، لازم است كه بذور در بسترى عارى از آلودگى كشت شوند و آبيارى آنها بهصورت كنترلشده و اندازه باشد. جمع شدن قطرات آب روى برى و ساقه كياه خصوصاً در شب كه هوا خنك است سبب افزايش بيمارى مىشود. براى انتقال نشاها به مزرعه بايستى نكات بهداشتى بهطور دقيق رعايت شود و ابزارآلات و دستكشهاى كاركران با مواد ضدعفونى مثل الكل اتيليك (•V V VD درصد) و وايتكس ضدعفونى شوند. نشاهايى كه بركهاى خشكيده و يا بركهاى رنغ يريده دارند بايد حذف شوند. در طول فصل زراعى كلخانهها و مزارع كشت كوجهفرنكى بلصورت مكرر بازديد و بوتههايى را كه نشانهاى مشكوك به بيمارى شانكر را نشان مىدهند كشيده و داخل يّلاستيك كذاشته و از مزرعه حذف شوند. در كلخانه راهروهاى بين رديفهاى كشت با مواد ضدعفونى كننده شسته شوند. علفهاى هرز خصوصاً علفهاى هرز سولاناسه بايستى كنترل شوند. برخى از اين علفهاى هرز، ميزبان اختيارى عامل بيمارى بوده و به بقاى بيمارگر كمك مى كنند. بهطور كلى، استفاده از بذور يا نشاهاى عارى از آلودگى، تيمار كردن بذور با آب گرم و يا وايتكس، تناوب زراعى سهساله با كياهان غير از خانواده سولاناسه، ريشهكنى كياهان آلوده و بقاياى كياهى بهجا مانده و استفاده از تركيبات مسى Garteman Zitter 1985, et al. 2003,) مىتواند در جلوكيرى و يا كم كردن بيمارى مؤثر باشند

\section{نتيجهَ}

Clavibacter michiganensis subsp. michiganensis بيمارى شانكر باكتريايى كوجهفرنكى ناشى از يكى از مهمترين بيمارىهاى اقتصادى گوجهفرنكى مىباشد. بيمارى انتشار جهانى داشته و خسارت زيادى به محصول گَوجهفرنكى وارد مى كند. جنانجه در مزرعهاى آلودگى به بيمارى شديد باشد ممكن است تا حدود 


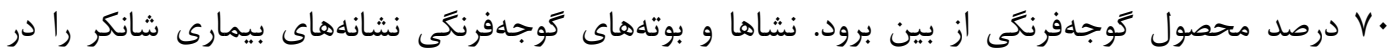
مراحل مختلف رشدى نشان مىدهند. عامل بيمارى با بذر، نشا، ميوه كوجهفرنكى، ذرات خاك، ابزارآلات كشاورزى، لباسهاى كاركران كشاورزى، قطرات آب و باد منتقل و منتشر مىشود و تا جند سال در خاك و مدت كمترى در بذر زنده مىماند. تاكنون بيمارى در برخى مناطق شمالغرب كشور ززارش شده است كه بايستى با مراقبت بيشتر و رعايت اصول قرنطينهاى از كسترش و انتقال بيمارى به ساير مناطق كشور

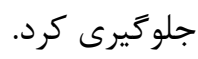

\section{References}

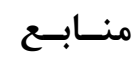

1. ارومجى س. سريץ ا. ارزيابى مقاومت ارقام مختلف ير محصول كوجهفرنگى به بيمارى شانكر باكتريايى در

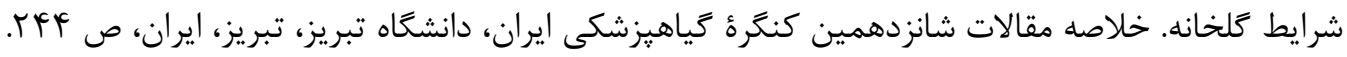
r. سهنديور آ. و صالحى س. rايץا. وقوع شانكر باكتريايى گوجهفرنكى در استان فارس. خلاصه مقالات

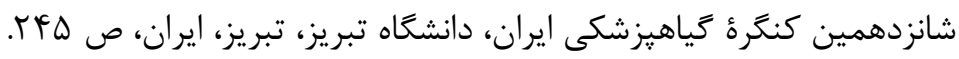

r. محمدىيور م. و رحيميان ح. IrVV ا. بررسى استرينهاى عامل بيمارى شانكر كوجهفرنكى در استان آذربايجان شرقى. خلاصه مقالات سيزدهمين كنكرة كياهيزشكى ايران، آموزشكده كشاورزى كرج، كرج،

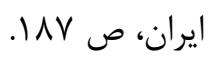

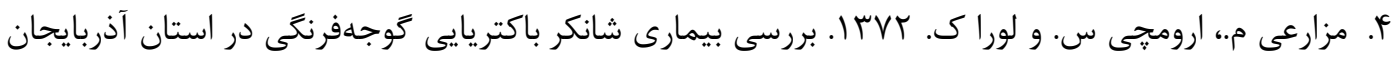
غربى. خلاصه مقالات يازدهمين كنكره كياهيزشكى ايران، دانشكاه كيلان، رشت، ايران، ص •19.

5. Agrawal K., Dilip Kumar S. and Vinod Kumar J. 2012. Seed-borne bacterial diseases of tomato (Lycopersicon esculentum Mill.) and their control measures: A Review. International Journal of Food, Agriculture and Veterinary Sciences, 2:173-182.

6. Behrendt U., Ulrich A., Schumann P., Nauman D. and Suzuki K. 2002. Diversity of grassassociated Microbacteriaceae isolated from the phyllosphere and litter layer after mulching the sward; polyphasic characterization of Subtercola Pratensis sp. nov., Curtobacterium herbarum sp. nov. and Platibacter flavus gen. nov., sp. nov. International Journal of Systematic and Evolutionary Microbiology 52:1441-1454. 
7. Garteman K. H., Kirchner O., Engemann J., Grafen I., Eichenlaub R. and Burger A. 2003. Clavibacter michiganensis subsp. michiganensis: Journal of Biotechnology 106:179-191

8. Gitaitis R. D. and Beaver R. W. 1990. Characterization of fatty acid methyl ester content of Clavibacter michiganensis subsp. michiganensis. Phytopathology 80:318-321.

9. Gleason M. L., Gitaitis R. D. and Ricker M. D. 1993. Recent progress in understanding and controlling bacterial canker of tomato in eastern north America. Plant Disease 77:10691076.

10. Goner A. S. 2014. Identification of the bacterium tomato stem canker. American Journal of Infectious Diseases 10:44.

11. Goto M. 1992. Fundamentals of Bacterial Plant Pathology. Academic Press Inc. Shizuoka Japan, 342 p.

12.Rat B. 1984. Corynebacterium michiganense Technique de détection dans les semences de tomato. pp. 35-35. In: Report on the 1st International Workshop on Seed Bacteriology, ISTA, Zürich, Switzerland.

13.Rat B., Poissonnier J., Goisque M. J. and Burgaud A. 1991. Le point sur le chancrebactérien. Fruit et Légumes 86:38-40.

14.Sabaratnam S. 2012. Bacterial canker of greenhouse tomato. https://news.gov.bc.ca/17494.

15.Schaad N. W. 2001. Laboratory Guide for Identification of Plant Pathogenic Bacteria. American Phytopathological Society,MN, USA, 373p.

16.Smith E. F. 1910. A new tomato disease of economic importance. Science, 31:794-796.

17.Thompson E., Leary J. V. and Chun W. W. C. 1989. Specific detection of Clavibacter michiganensis subsp. michiganensis by homologous DNA probe. Phytopathology 79:311314.

18.Vaerenbergh, J. V. and Chauveau, J. F. 1987. Detection of Corynebacterium michiganense in tomato seed lots 1. EPPO Bulletin, 17:131-138.

19.Zitter T. A. 1985. Bacterial diseases of tomato. Compendium of Tomato Diseases. The American Phytopathological Diseases 2:12-22. 